\title{
Kosmopolitanisme dalam Industri Musik Dangdut Madura pada Tahun 2000-an di Situbondo
}

Panakajaya Hidayatullah

Pada tahun 2000-an, industri musik lokal di Situbondo mengalami puncak kejayaan dengan banyak memproduksi kaset-kaset dan VCD. Kaset dan VCD merupakan produk kultural lintas budaya, etnis, dan geografis yang terangkum dalam kemasan industrial. Seperti halnya dalam industri rekaman dangdut Madura di Situbondo, sebelum menjadi produk kaset dan VCD, ia melalui tahapan yang rumit yakni direkam di Situbondo oleh produser; diduplikasi dan dikemas oleh perusahaan rekaman lokal di Jember, Surabaya, Banyuwangi dan Jakarta; kemudian di pasarkan ke beberapa wilayah Jawa Timur dan ke beberapa wilayah diaspora masyarakat Madura, bahkan ke luar negeri dimana banyak masyarakat Madura bekerja sebagai TKI. Dangdut Madura tidak hanya dinikmati dan direproduksi oleh masyarakat Madura saja, hampir sebagian pemilik perusahaan lokal justru beretnis Tionghoa, beberapa musisi yang melakukan rekaman di Surabaya juga beretnis Jawa. Secara musikal Dangdut Madura merupakan hasil adaptasi dan apropriasi dari racikan idiom musikal berbagai kebudayaan. Beberapa diantaranya mengadaptasi musik India, Arab, Pop Barat, Pop Indonesia, Kendang Kempul (Banyuwangi), Campursari (Jawa), Gendhing (Madura), dan musik disko (Barat). Musik dangdut Madura merangkum keberagaman budaya di Indonesia. $\mathrm{Hal}$ ini menunjukkan bahwa budaya bersifat dinamis dan terbuka terhadap budaya lain. Melalui musik dangdut Madura orang bisa merasakan unsur-unsur budaya yang beragam. Peran musikal dangdut Madura mampu membangun kesadaran terhadap perbedaan yang ada dalam kehidupan masyarakat.

\section{Pendahuluan}

Industri rekaman lokal di Situbondo lahir dan mulai berkembang sejak akhir 1960-an, bersamaan dengan berkembangnya teknologi perekaman kaset pita pada industri rekaman nasional (Hidayatullah, 2017: 96; Theodore K.S, 2013: 57). Sebelumnya bisnis industri rekaman di Situbondo hanya berjalan pasif, artinya belum ada perusahaan rekaman lokal yang mampu memproduksi produk rekaman. Beberapa di antaranya hanya berperan sebagai distributor dan penjual produk-produk (kaset dan piringan hitam) industri rekaman nasional dan internasional. Di Situbondo pada tahun 1960-an, setidaknya ada beberapa toko dan distributor yang terkenal seperti Toko Warna yang menjual produk-produk piringan hitam, serta toko Sampurna dan Diamond yang menjual produk-produk kaset. Produk piringan hitam di Situbondo kurang begitu diminati, peminatnya terbatas pada segmentasi kelas tertentu. Hanya kalangan kelas menengahatas yang bisa menikmatinya.

Perkembangan teknologi dari piringan hitam ke teknologi kaset pada tahun $1963^{1}$ memberi pengaruh yang cukup signifikan terhadap perkembangan industri rekaman. Kemudahan untuk memproduksi dan menduplikasi kaset pita membuat banyak pihak ikut-ikutan memproduksinya

\footnotetext{
${ }^{1}$ Peralihan teknologi PH ke kaset sebenarnya dimulai sejak tahun 1963. Ketika Philips memperkenalkan produksi audio-kaset pertama yang menggunakan polister 1-8 inci berkualitas tinggi, BASF (Budische Anilin Und Soda Fabrik) buatan Jerman Barat. Philip juga memproduksi tape recorder portable (alat untuk memutar kaset pita) yang pertama kali beredar di Eropa, digerakkan oleh baterai dan masih menggunakan system mono (Theodore, K.S, 2013: 56)
} 
baik yang resmi maupun 'gelap' (bajakan) (Theodore, K.S.. 2013: 57). Pada periode inilah kemudian lahir industri rekaman lokal di Situbondo. Perusahaan rekaman lokal pertama yang mengawali produksi kaset pita ialah Sampurna Record. Sebelum menjadi perusahaan rekaman lokal, Sampurna Record adalah toko sekaligus distributor kaset-kaset rekaman nasional dan internasional.

Perbedaan industri rekaman nasional dan lokal terletak pada konten sajian, artis, segmentasi pasar, dan jangkauan pangsa pasar atau area distribusinya. Industri rekaman lokal hanya berisi konten sajian yang bersifat lokal seperti rekaman musik tradisi dan seni pertunjukan rakyat. Artis yang mengisi rekaman adalah artis lokal, segmentasi serta area distribusinya terbatas pada kalangan etnik atau komunitas tertentu (Hidayatullah, 2017: 97). Salah satu produk industri rekaman lokal yang paling populer dan diminati oleh masyarakat Situbondo adalah dangdut Madura.

Industri rekaman lokal (dangdut Madura) memiliki motivasi untuk mengembangkan khasanah kebudayaan lokal. Dalam dunia industri hal ini bisa dibaca sebagai upaya pembedaan (diversivikasi) terhadap industri rekaman nasional dan internasional. Perusahaan rekaman lokal dalam hal ini mempunyai peran dalam menyediakan produk alternatif bagi masyarakat di daerah dan terbukti bahwa produk rekaman lokal selalu menjadi pilihan utama masyarakat daerah. Puncak kejayaan industri rekaman lokal di Situbondo terjadi ketika hadirnya teknologi Video CD (VCD) di tahun 2000-an. Pada tahun tersebut, di Situbondo banyak bermunculan perusahaan rekaman lokal baru yang ikut memproduksi kaset dan VCD dangdut Madura seperti Rahayu Inti Fantasi Record, Handayani Record, Habibah Record, Giant Record, Multinada Record, Maju Jaya Makmur Record, Ya Record, dan HNH Record.

Industri rekaman lokal di Situbondo yang notabene bersifat lokal dan mengusung semangat lokalitas, justru bukan diinisiasi oleh masyarakat etnik Madura sendiri melainkan masyarakat komunitas Cina ${ }^{2}$. Hubungan antara komunitas Cina dan Madura di Situbondo memang sudah terjalin sejak lama. Dalam industri rekaman lokal, hubungan itu berlangsung dalam bentuk kerjasama (mitra). Salah satu contohnya dapat dilihat dalam struktur manajemen bisnis di Sampurna Record dan Diamond Record. Perusahaan rekaman Sampurna Record diinisiasi dan dimiliki oleh Pinpin, sedangkan Diamond record dimiliki oleh Gie Tek yang notabene keduanya merupakan bagian dari masyarakat komunitas Cina, namun dalam bidang kerja produksinya, ia mempekerjakan masyarakat komunitas Madura. ${ }^{3}$ Masyarakat komunitas Madura tidak hanya diposisikan sebagai pekerja yang menerima perintah teknis saja, namun juga menentukan kebijakan-kebijakan produksiya, misalnya menentukan tema, menentukan artis, membuat lagu, mengaransemen lagu, mendesain suara dan sebagainya. Seringkali pemilik perusahaan juga memberikan pelatihan dan pendidikan kepada pekerjanya dengan mendatangkan teknisi dari perusahaan rekaman lokal di luar Situbondo. Pemilik perusahaan juga memberikan berbagai fasilitas kepada pekerjanya, seperti alat transportasi ketika melakukan rekaman di lapangan (acara pernikahan), fasilitas rekaman serta tempat tinggal. ${ }^{4}$

Dalam artikel ini akan dibahas perihal fenomena kosmopolitan dalam industri musik dangdut Madura pada tahun 2000-an di Situbondo. Benedict Anderson menjelaskan konsep kosmopolitan melalui sosok Kwee Thiam Tjing seorang jurnalis Cina-Indonesia yang miskin sebagai berikut,

\footnotetext{
${ }^{2}$ Pemilihan penggunaan istilah Cina berdasarkan pada pertimbangan lokal etnografis. Masyarakat Situbondo masih kerap menggunakan kata Cina sejak dulu hingga sekarang untuk menyebut etnis Tionghoa dan peranakannya. Secara Nasional, sebutan Cina cenderung diganti dengan Tionghoa.

${ }^{3}$ Wawancara dengan Imam Kutunuk selaku Budayawan Situbondo pada tanggal 21 Oktober 2017

${ }^{4}$ Wawancara dengan Arif selaku pemilik perusahaan rekaman Rahayu Inti Fantasi Record dan Maju Jaya Makmur Record pada tanggal 23 Juli 2017
} 
"In terms of colonial cosmopolitanism, I thought it was interesting because this guy was absolutely a cosmopolitan, but he almost never went anywhere-not even to China, as many of his Chinese acquaintances did. So I had to think about cosmopolitanism to talk about Kwee".

Dalam wawancaranya Anderson memaknai Kwee sebagai potret kosmopolitanisme. Kwee adalah keturunan Tionghoa yang sudah tinggal lama di Indonesia. la mampu berbicara menggunakan empat bahasa yakni bahasa Hokkien, Jawa, Belanda dan Indonesia mesikipun ia tidak pernah pergi kemanapun. Walaupun keluarganya telah berada di Indonesia selama 300 tahun, namun kebijakan Belanda selalu memisahkan dirinya sebagai orang Tionghoa dengan penduduk asli. Hal ini membuat Kwee sangat menyadari fakta bahwa ia bukan penduduk asli negara itu, walaupun ia sangat patriotik terhadap negara. ${ }^{6}$

Kosmopolitan dalam diri Kwee mengandung arti bahwa di dalam dirinya terdapat berbagai gabungan dan perlintasan kebudayaan. Dalam dangdut Madura konsep kosmopolitan terkandung dalam kaset dan VCD dangdut Madura, yang menandakan adanya perlintasan berbagai kebudayaan di dalamnya.

\section{Metodologi}

Penelitian ini merupakan penelitian antropologi musik yang menggunakan pendekatan multidisiplin. Pendekatan multidisiplin diperlukan karena data kualitatif bersifat multidimensi. Metode yang digunakan dalam penelitian ini adalah metode etnografi. Dalam penelitian ini digunakan beberapa tahapan yakni 1) pengumpulan data; dan 2) pengolahan data. Langkahlangkah dalam pengumpulan data secara teknis menggunakan langkah dalam metode etnografi baru James P. Spadley dengan menyesuaikan dan menambahkan beberapa elemen yang mendukung (Spradley, 2006). Langkahnya ialah 1) observasi partisipatoris; 2) menetapkan informan; 3) mewawancarai informan; 4) membuat catatan etnografi; 5) mengajukan pertanyaan deskriptif; 5) melakukan analisis wawancara; dan 6) kajian literatur.

Data yang sudah terkumpul kemudian diklasifikasi berdasarkan kelompok dan kategori masing-masing guna dilakukan pengolahan dan analisis data. Klasifikasi data dilakukan dengan berdasar atas keterkaitan teori yang diaplikasikan dalam penelitian. Data yang sudah diklasifikasi dilihat pola dan hubungan antar datanya kemudian dilakukan analisis secara interpretatif

\section{Pertemuan Kebudayaan Barat-Lokal melalui Kaset dan Vcd Musik Dangdut Madura}

Musik dangdut Madura dalam produksi industri rekaman lokal di Situbondo merupakan bentuk komersialisasi musik lokal. Pada awalnya musik dangdut Madura bukan sebuah komoditi ekonomi melainkan musik yang memiliki fungsi sosialnya sendiri dalam masyarakat. Jika ditinjau dari sejarahnya, musik dangdut Madura lahir dari pertunjukan drama AI Badar Lesbumi di tahun 1960-an (Hidayatullah, 2017: 48). la memiliki fungsi untuk mengiringi drama Al Badar dalam kegiatan syiar Islam di Situbondo.

Masuknya teknologi perekaman, menjadi sebuah penanda awal masuknya budaya Barat dalam musik. Kontak kebudayaan terjadi ketika masyarakat lokal mulai mengenal teknologi perekaman menggunakan media kaset. Teknologi kaset secara signifikan juga mengubah sistem

\footnotetext{
${ }^{5}$ Wawancara Cynthia Foo dengan Benedict Anderson, diakses melalui laman www.antropologi.info pada tanggal $09-11-2017$.

${ }^{6}$ Wawancara Cynthia Foo dengan Benedict Anderson, diakses melalui laman www.antropologi.info pada tanggal $09-11-2017$.
} 
kerja berkesenian masyarakat. Beberapa jenis kesenian (seni pertunjukan) masyarakat kemudian dapat didokumentasikan dengan mudah. Seiring berjalannya waktu, hal tersebut mampu dimanfaatkan dengan jeli oleh masyarakat komunitas Cina. Musik dangdut Madura kemudian diproduksi dengan mekanisme industrial. Industri rekaman lokal dapat dibaca sebagai pintu masuk budaya melalui proses pembuatan kaset. Melalui produk rekaman lokal (kaset) dapat dilihat adanya budaya yang terangkum di dalamnya. Penggunaan musik dangdut Madura dalam produksinya adalah salah satu budaya lokal yang masuk.

Masuknya teknologi Barat beserta perkembangannya dalam industri musik dangdut Madura dapat dimaknai sebagai perpanjangan dari bisnis industri internasional. Industri rekaman yang dibawa oleh kebudayaan Barat juga mempengaruhi masyarakat tentang bagaimana orang harus memanajemen musik. la menawarkan sebuah sistem modern, karakter modern yang paling kentara adalah model birokrasi. Hampir semua perusahaan rekaman lokal di Situbondo menerapkan sistem kerja tersebut. Setiap pekerja diberi job description-nya (pembagian/divisi pekerjaan) masing-masing. Umumnya mereka dibagi berdasarkan jenis pekerjaannya seperti, penulis lagu, arranger (composer), sound engineer (operator), teknisi, musisi, penyanyi, distributor, sales marketing (pemasaran), dan sebagainya. Setiap jabatan akan mendapatkan upah yang berbeda, tergantung dari besaran beban kerjanya.

Pada era teknologi VCD, pertemuan kebudayaan berlangsung lebih kompleks. Jika dalam kaset, budaya lokal (Madura) direpresentasikan dalam bentuk suara (audio), kini budaya lokal tampil secara audio-visual. Di era VCD, musik dangdut Madura dikemas dengan mengadaptasi kemasan musik nasional dan internasional dengan menampilkan format video clip. Dalam bentuknya yang baru, secara visual budaya lokal direpresentasikan melalui video pemandangan objek wisata, kostum tradisi dan tari-tarian lokal. Salah satu contohnya dapat dilihat dalam gambar 1, yaitu cuplikan video clip lagu dangdut Madura berjudul Tatandung yang menampilkan gambar pemandangan objek wisata pantai pasir putih di Situbondo.

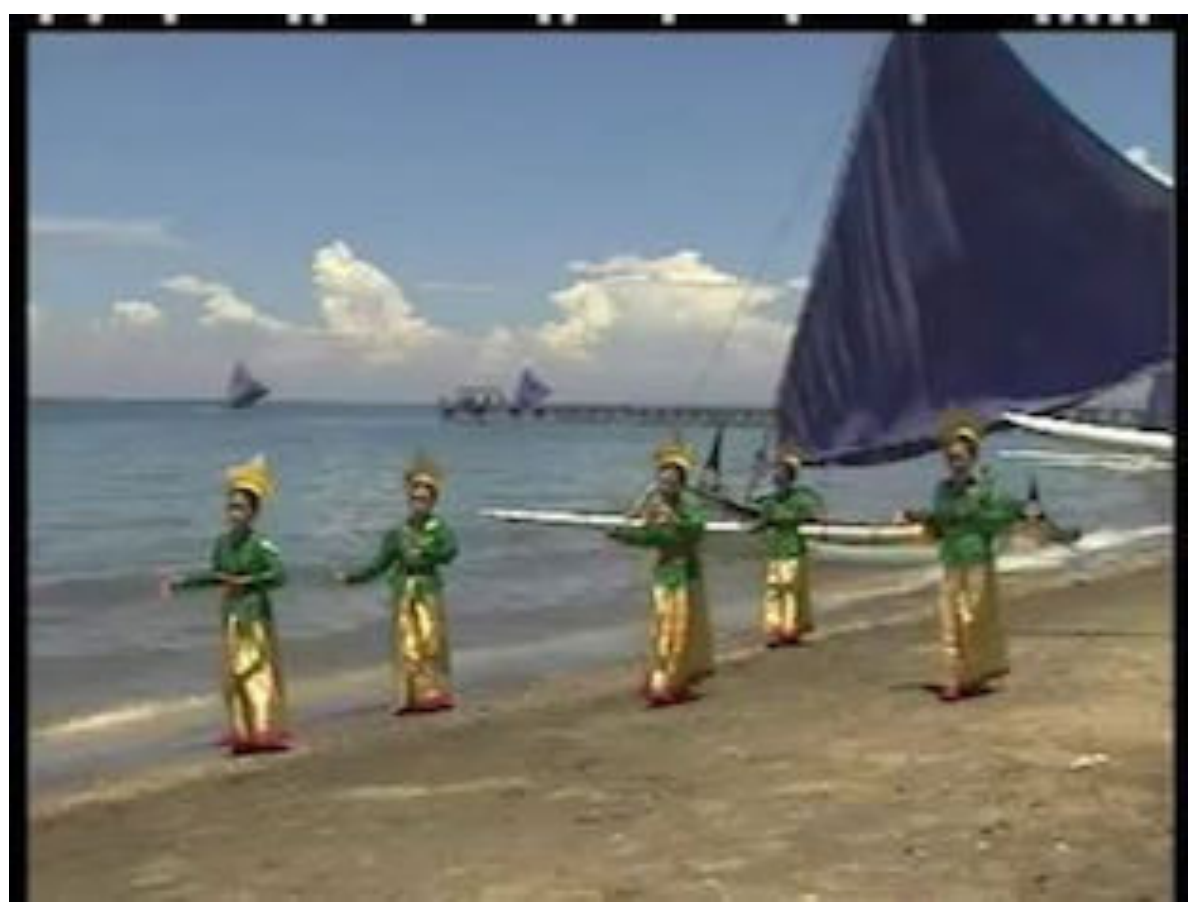

Gambar 1: Pemandangan Objek Wisata Pasir Putih di Situbondo (Sumber: Cuplikan lagu dangdut Madura berjudul Tatandung) 


\section{Musik Dangdut Madura sebagai Apropriasi Lintas Kebudayaan}

Musik dangdut Madura adalah salah satu bentuk ekspresi masyarakat Madura di Situbondo. Menurut Turner ekspresi adalah sebuah pengungkapan kristalisasi dari suatu pengalaman hidup manusia. Ekspresi memiliki relasi dengan pengalaman masyarakat dalam sebuah kebudayaan (Bruner dan Turner, 1986: 5-9). Maka dari itu melalui musik dangdut Madura, dapat dilihat bagaimana masyarakat Situbondo mengartikulasikan identitas dirinya. Masyarakat Situbondo merupakan masyarakat multikultur, terdapat beberapa etnik yang mendiami kawasan tersebut seperti Madura, Jawa, Osing, Arab, Cina dan lainnya. Secara kuantitas, masyarakatnya didominasi oleh masyarakat Madura migran yang bermigrasi ke daerah ini sejak sebelum abad ke 19 (Husson, 1997: 79). Masyarakat Madura-nya pun beragam dan kompleks jika ditinjau dari dialek bahasa serta corak kebudayaannya.

Musik dangdut Madura merupakan produk apropriasi kebudayaan masyarakat Madura Situbondo. Seperti halnya musik dangdut yang secara musikal merupakan ramuan dari berbagai idiom musik lintas kebudayaan, dangdut Madura juga mengalami hal serupa. Secara musikal terdapat beberapa idiom musik dari berbagai kebudayaan yang saling berinteraksi satu sama lainnya dalam satu bentuk musik. Beberapa idiom musik tersebut antara lain, musik tradisional Madura, musik Nasional, musik Barat, musik India, musik Arab, musik Banyuwangen, musik Jawa, dan lainnya.

Unsur idiom musikal tersebut terepresentasi dalam berbagai bentuk, baik dalam bentuk irama, skala (scale), warna suara (timbre), gaya vokal, struktur lagu, dan melodi vokal. Dalam bentuk irama terdapat beberapa unsur yang bisa diklasifikasi antara lain adalah irama dangdut asli (piur). Dangdut asli adalah irama yang umum digunakan oleh beberapa orkes melayu di tahun 70-an, termasuk Rhoma Irama, Elvi Sukaesih dan Evie Tamala. Irama dangdut asli mencerminkan identitas nasional. Dalam dangdut Madura unsur ini bisa ditemukan dalam lagu yang sumber penciptaannya megadaptasi lagu dangdut nasional seperti lagu "Yatim Piatu" yang mengadaptasi lagu "Akhir Sebuah Cerita". Selain irama dangdut asli, juga terdapat irama yang lain seperti irama Campursari Jawa pada lagu Mano' Bellug, irama Kendang Kempul Banyuwangi pada lagu "Abhântal Dâdâ", Rock, dan disko yang mencerminkan identitas budaya Barat seperti dalam lagu "Karè Ngandung". Musik dangdut Madura tidak hanya menggunakan skala diatonis namun juga menggunakan skala musik tradisi (pentatonis slendro) yang mencerminkan kebudayaan Madura seperti pada lagu "Duh Angin".

Unsur musik yang paling mendominasi dan menjadi 'citra' dangdut Madura adalah unsur musik film India. Hampir sebagian besar karya-karya dangdut Madura adalah hasil adaptasi dari lagu-lagu film India. Kedekatan budaya Madura dengan India di Situbondo terjalin sejak adanya politik anti imperialis Sukarno yang mengecam penayangan film-film Barat, namun sebagai gantinya ia membuka pintu masuk bagi film-film populer India dan Timur Tengah (Weintraub, 2012: 64). Di era tersebut kemudian lahir seni drama Al Badar Lesbumi yang bentuknya mengadaptasi film-film India di bioskop. Dari sinilah cikal bakal musik dangdut Madura lahir.

Melalui keberagaman ekspresi kebudayaan yang terepresentasikan dalam musik dangdut Madura, bisa dikatakan bahwa kebudayaan tidaklah bersifat eksklusif. Dalam dangdut Madura terlihat berbagai unsur kebudayaan saling menjalin interaksi musikal secara harmonis. Penyatuan unsur tersebut tentunya juga didukung oleh masyarakat penikmatnya yang terbuka atas keragaman budaya tersebut. 


\section{Perlintasan Geografis - Budaya Dalam Industri Kaset Dan Ved Dangdut Madura}

Proses produksi musik dangdut Madura dalam industri rekaman lokal di Situbondo berlangsung melalui berbagai tahapan. Pada mulanya seorang produser rekaman akan mencari artis lokal yang akan diajak rekaman, hingga kemudian melakukan rekaman baik di studio ataupun sistem rekaman langsung (live) di acara hajatan. Perusahaan rekaman lokal di Situbondo umumnya hanya memproduksi master rekaman saja, sedangkan penggandaan atau duplikasinya dialakukan di perusahaan rekaman yang lebih besar seperti di Jember, Surabaya, Banyuwangi dan Jakarta.

Contoh proses produksi rekaman lokal di Situbondo dapat dilihat dalam produksi kaset milik Rahayu Inti Fantasi (RIF) Record dan produksi VCD milik Maju Jaya Makmur (MJM) Record. RIF awalnya hanyalah toko dan distributor kaset, namun kemudian berkembang menjadi perusahaan rekaman. RIF adalah perusahaan rekaman lokal yang terbilang kecil karena tidak didukung oleh teknologi yang memadai. RIF dalam hal ini hanya merekam musik dangdut Madura dalam bentuk kaset. Hasil rekaman tersebut berbentuk kaset master, yang kemudian dijual dan digandakan di beberapa perusahaan rekaman yang menjalin kemitraan seperti Pinokio atau Pelangi Sutera Record di Jember dan Ria Record di Banyuwangi. Selanjutnya kaset akan digandakan dan kemudian didistribusikan ke berbagai daerah. Walaupun perusahaan yang menggandakan memiliki hak sepenuhnya atas produk kaset tersebut namun ia hanya menjual dan mendistribusikan kaset itu melalui satu pintu lewat toko milik RIF. ${ }^{7}$ Berikut contoh sampul kaset dangdut Madura yang diproduksi oleh RIF Record bekerjasama dengan Pelangi Sutera Record.

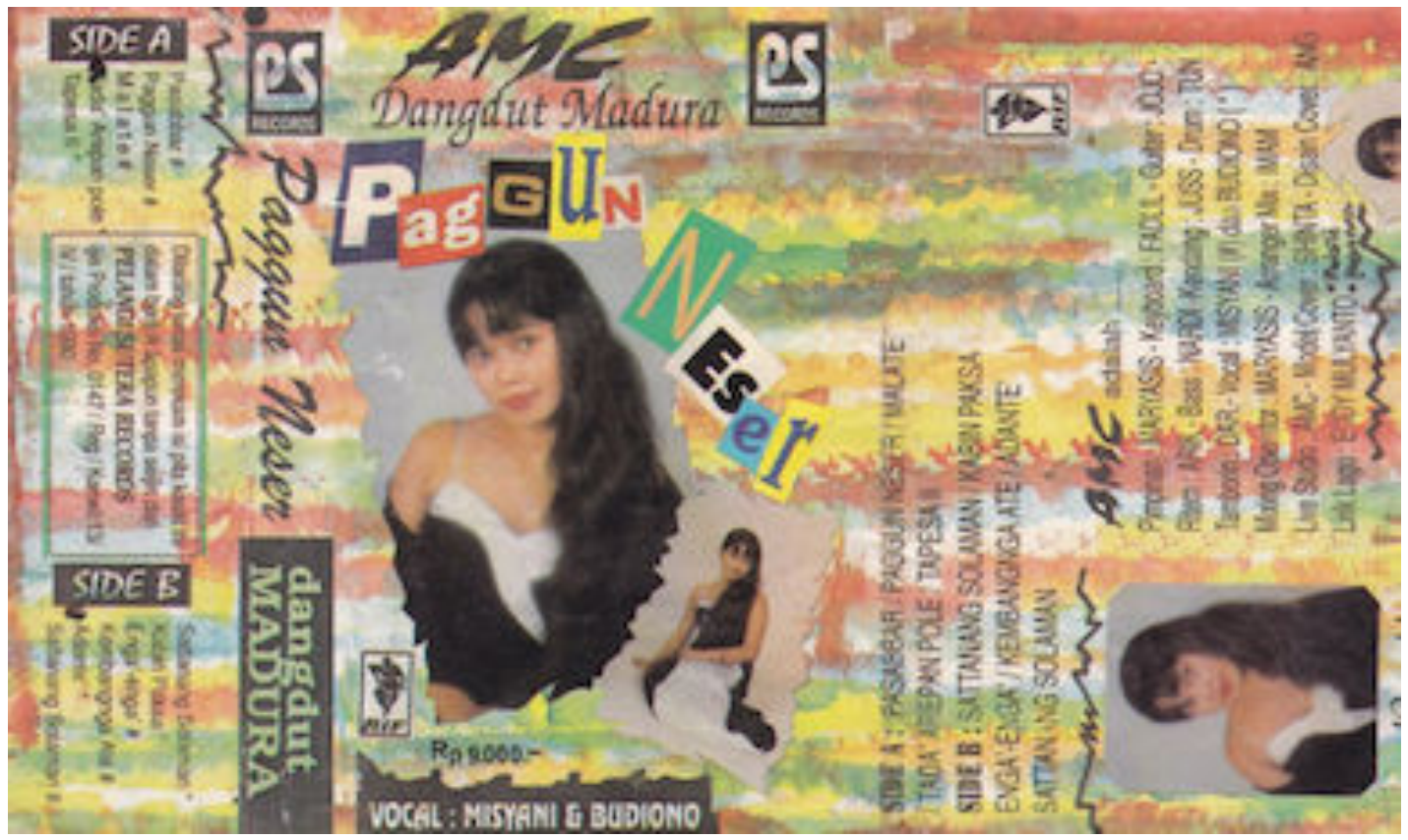

Gambar 2: Sampul kaset Dangdut Madura produksi RIF Record kerja sama dengan Pelangi Sutera (PS) Record (Sumber: Koleksi pribadi)

Pada gambar sampul di atas ada dua logo perusahaan rekaman lokal yang tertera di dalamnya, yakni RIF Record dan PS Record. Logo tersebut menandakan bahwa kaset tersebut

\footnotetext{
${ }^{7}$ Wawancara dengan Arif selaku pemilik perusahaan rekaman Rahayu Inti Fantasi Record dan Maju Jaya Makmur Record pada tanggal 23 Juli 2017
} 
merupakan produksi hasil kerja sama dari dua perusahaan rekaman lokal yakni RIF Record di Situbondo dan PS Record di Jember.

Begitupun juga dengan proses produksi VCD milik MJM Record. MJM Record sebenarnya satu perusahaan dan satu kepemilikan dengan RIF Record, hanya saja MJM memproduksi bentuk VCD saja. Sama seperti penggandaan kaset oleh RIF, MJM juga melakukan penggandaan cakram VCD melalui hubungan kemitraan dengan perusahaan rekaman lain. MJM Record melakukan penggandaan cakram VCD di perusahaan rekaman nasional di Jakarta, karena perhitungan kualitas yang lebih baik. ${ }^{8}$

Selain melalui tahap rekaman master di perusahaan rekaman lokal Situbondo, terkadang para pelaku seni (penulis lagu) juga melakukan rekaman langsung di perusahaan rekaman luar Situbondo. Seperti yang sering dilakukan oleh As'ad Musahra dan S.Pandi. Sebagai penulis lagu mereka langsung diundang untuk melakukan rekaman di perusahaan rekaman lokal di Surabaya. Lagu ciptaannya kemudian direkam oleh beberapa musisi Surabaya (beberapa di antaranya bukan dari etnis Madura), hingga kemudian diproduksi, digandakan dan didistribusikan. ${ }^{9}$ Dalam tahap produksi musik, bisa digambarkan bahwa industri kaset dan VCD dangdut Madura telah menjalani berbagai perlintasan geografis - budaya, bukan hanya geografis-budaya Madura saja. Sebagai sebuah produk kebudayaan lokal, ia tidak terbatas (terikat) pada wilayah geografis budaya tertentu, namun telah menyebar menembus batas-batas geografis - budayanya.

Dalam wilayah distribusi, musik dangdut Madura diedarkan di berbagai wilayah. Anto menyatakan bahwa,

"Distribusi kaset dan VCD dangdut Madura itu kalau ke Utara sampai ke Sumenep dan beberapa daerah di pulau Madura. Ke arah Barat sampai ke Surabaya dan Pasuruan. Ke arah Timur sampai ke Bali dan Banyuwangi. Ke arah Selatan sampai ke Jember dan Lumajang". 10

Berdasarkan pernyataan Anto di atas, dapat dilihat jangkauan pasar produk industri musik dangdut Madura di Situbondo. Wilayah distribusi tersebut secara garis besar adalah wilayah yang di dalamnya terdapat persebaran masyarakat etnik Jawa-Madura. Selain di wilayah tersebut, sebenarnya produk industri musik dangdut Madura juga menyebar sampai ke luar Indonesia. Anto mengatakan bahwa,

"Penikmat musik dangdut Madura tidak hanya terbatas di kawasan Jawa Timur, tapi juga banyak tersebar di luaran. Handayani Record dulu sempat berlangganan mengirim produk VCD ke Malaysia. Saudara TKI di sana juga banyak orang Madura, dan mereka itu fans dangdut Madura".

Pernyataan Anto menjelaskan bahwa wilayah lingkup persebaran industri dangdut Madura tidak terbatas pada sebaran wilayah distribusinya. Hal ini juga menandakan bahwa musik dangdut Madura memiliki penikmat yang tidak terbatas pada wilayah Jawa Timur saja, namun tersebar dimana-mana termasuk di seluruh wilayah diaspora masyarakat Madura.

\footnotetext{
${ }^{8}$ Wawancara dengan Arif selaku pemilik perusahaan rekaman Rahayu Inti Fantasi Record dan Maju Jaya Makmur Record pada tanggal 23 Juli 2017

${ }^{9}$ Wawancara dengan S. Pandi selaku penulis lagu dangdut Madura pada tanggal 23 Juni 2016 di Ramban, Bondowoso

${ }^{10}$ Wawancara dengan Anto selaku Sound Engineer di perusahaan rekaman Handayani Record pada tanggal 22 Juni 2017 di Situbondo

${ }^{11}$ Wawancara dengan Anto selaku Sound Engineer di perusahaan rekaman Handayani Record pada tanggal 22 Juni 2017 di Situbondo
} 


\title{
6. Inklusi Budaya dalam Menikmati Kaset dan VCD Musik Dangdut Madura
}

Musik dangdut Madura saat ini sudah menjadi bagian yang tidak bisa dilepaskan dari kehidupan masyarakat Situbondo. Hal ini bisa diamati dari fenomena-fenomana di lapangan. Hampir semua stasiun radio dan TV lokal menyajikan musik dangdut Madura. Musik ini juga dapat dengan mudah ditemui di ruang-ruang publik seperti di Pasar Mimbaan Baru, Alun-Alun Kota juga di pasar-pasar tradisional dimana terdapat lapak-lapak kaki lima yang menjual produk kaset dan VCD tersebut. Setiap radio di Situbondo memiliki fans dangdut Madura, beberapa di antara mereka juga membuat komunitas pencinta dangdut Madura. Secara rutin mereka berkumpul di radio, untuk bernyanyi bersama, dan membuat acara-acara rutin seperti lomba karaoke dangdut Madura. $^{12}$

Dangdut Madura dalam media kaset saat ini sudah jarang diminati oleh masyarakat Situbondo, namun bukan berarti penikmat kaset sudah tidak ada lagi. Di daerah Situbondokota setidaknya masih ada dua toko kaset yang beroperasi dan menjual kaset dangdut Madura yakni toko Bagong dan satu kios kecil di lantai dua Pasar Mimbaan Baru. Toko Bagong adalah toko kaset terbesar di Situbondo yang berdiri sejak tahun 1970-an. Menurut Enni Silvana selaku pemilik toko Bagong mengatakan bahwa,

\begin{abstract}
"Sebenarnya dulu kaset dangdut Maduraan banyak dan sangat laris di sini, apalagi di kawasan Pasar Mimbaan Baru. Lagunya enak-enak mas, dulu saya punya banyak koleksi produksinya Pinokio. Tapi sekarang produksinya macet, Pinokio juga sudah bangkrut sekarang. Selain itu peminat kaset juga sudah berganti ke VCD, sudah jarang orang yang pakai tape. Sebenarnya saya sudah mau berhenti bisnis kaset tapi setelah saya pikirpikir, saya kasian dengan beberapa pelanggan tetap saya yang selalu mencari kaset disini. Jadi motivasi saya jualan sekarang selain cari bathi (untung) ya untuk melayani orang-orang penggemar kaset, salah satunya ya kaset Maduraan".
\end{abstract}

Perlu dijelaskan bahwa pemilik toko Bagong adalah masyarakat komunitas Cina. Enni sebagai masyarakat komunitas Cina tidak membatasi ruang dengarnya. la mengakui bahwa dulunya sempat menjual dan memiliki koleksi kaset dangdut Madura produksi Pinokio Record. Hal yang menarik juga dapat dilihat dari motivasinya menjual kaset tersebut yaitu untuk melayani para penggemar dangdut Madura. Ada semacam ikatan kultural yang terjalin sangat intim antara penjual kaset (komunitas Cina) dengan pembelinya (masyarakat lokal). Ikatan tersebut melebihi dari sekedar transaksi ekonomi biasa.

Selain melalui kaset, musik dangdut Madura secara auditif juga bisa dilihat dalam konteks media radio. Fans dangdut Madura di radio terdiri atas berbagai macam latar belakang etnis, dan tidak semuanya adalah masyarakat etnis Madura. Reno seorang penyiar program dangdut Madura di radio mengatakan bahwa,

"Penggemar dangdut Madura di Radio Bhasa FM ini beragam bahkan ada yang dari Singaraja Bali, dia itu orang Bali asli yang sebenarnya tidak tahu dengan bahasa Madura, tetapi setiap hari dia selalu gabungan dan request lagu dangdut Madura". ${ }^{14}$

Sama halnya dengan pernyataan Reno, penulis juga mendapati beberapa fans yang selalu hadir di studio siaran radio Suara Pasar Mimbaan memiliki latar belakang etnis Jawa, salah satunya adalah Karyono. Berikut pengamatan penulis di lapangan,

\footnotetext{
${ }^{12}$ Observasi di radio Suara Pasar Mimbaan Situbondo selama 3 bulan pada bulan April - Juni 2016

${ }^{13}$ Wawancara dengan Enni Silvana selaku pemilik toko kaset Bagong di Situbondo pada tanggal 27 Oktober 2017

${ }^{14}$ Wawancara dengan Reno selaku penyiar radio Bhasa FM di Situbondo pada tanggal 18 April 2016 
"Setiap pukul 21.00 malam, secara rutin Karyono selalu hadir ke studio siaran radio Suara Pasar Mimbaan. Karyono adalah seorang pedagang mie ayam yang memiliki latar belakang etnis Jawa. la sangat senang dengan musik dangdut Madura, bahkan di warung mienya, ia memasang speaker untuk memonitori program radio kesukaannya". ${ }^{15}$

Selain dua fans di atas, ada seorang fans program acara musik dangdut Madura di radio Suara Besuki Indah (SBI) yang bernama udara Mama Ratan, ia adalah seorang pendatang dari daerah Jawa Tengah yang juga sangat menyukai lagu dangdut Madura. Walaupun bahasanya kurang dimengerti namun menurutnya musik dan melodinya mampu membangkitkan emosi. la secara rutin mendengarkan musik dangdut Madura secara auditif melalui radio SBI. Baginya musik dangdut Madura dapat menjadi teman dan hiburan dikala mengerjakan pekerjaan rumah. ${ }^{16}$

Dalam media audio-visual, musik dangdut Madura bisa dinikmati melalui siaran TV lokal dan VCD. Musik dangdut Madura di TV lokal dan VCD biasanya digunakan oleh masyarakat di ruang-ruang privat dan publik. Berikut pengamatan penulis terhadap penggunaan media VCD dalam menonton dangdut Madura oleh masyarakat di lapak kaki lima,

"Di pinggiran Pasar Mimbaan Baru, berderet pedagang kaki lima yang menjual cakram VCD. Mereka memutar cakram VCD lokalan terbaru sepanjang hari untuk memancing pembeli. Ketika pemilik lapak memutar, beberapa pekerja di sekitar lapak tersebut kemudian memperhatikan lagunya. Ada beberapa yang mendekat lalu menonton bersama dan mengomentari lagu tersebut". ${ }^{17}$

\section{Kesimpulan}

Berdasarkan pembahasan di atas, dapat disimpulkan bahwa kosmopolitan dalam industri musik dangdut Madura pada tahun 2000-an di Situbondo dapat ditelaah melalui berbagai aspek. Di antaranya adalah 1) pertemuan kebudayaan Barat dan lokal melalui kaset dan VCD, yang ditandai dengan penggunaan teknologi perekaman dan sistem manajerial bisnis industri berorientasi Barat; 2) Musik dangdut Madura sebagai apropriasi lintas kebudayaan, yang secara musikal terepresentasikan dalam racikan berbagai idiom lintas kebudayaan seperti idiom musik tradisional Madura, Nasional, Barat, India, Arab, Banyuwangen, Jawa, dan lainnya; 3) Perlintasan geografis - budaya dalam industri musik dangdut Madura, dilihat dari proses produksi, distribusi dan konsumsi yang melintasi berbagai daerah, negara, etnik dan bahasa; 4) Inklusi budaya dalam menikmati kaset dan VCD, berupa penerimaan budaya oleh masyarakat dengan berbagai latar belakang kebudayaan di Situbondo melalui musik dangdut Madura.

Budaya dalam hal ini mempunyai peran dalam mengintegrasikan masyarakat. Dalam konteks musik dangdut Madura, fungsi eksklusif dalam sebuah kebudayaan dapat dibantah. Budaya Madura bukan hanya milik masyarakat Madura, namun juga dapat diterima dan berdialog dengan budaya lainnya. Melalui industri musik dangdut Madura unsur budaya Cina, Arab, India, Nasional, Jawa dan Banyuwangi bersatu padu dalam musik yang harmonis.

\section{Daftar Pustaka}

\footnotetext{
${ }^{15}$ Observasi di radio Suara Pasar Mimbaan Situbondo selama 3 bulan pada bulan April - Juni 2016

${ }^{16}$ Wawancara dengan Mama Ratan selaku fans radio Suara Besuki Indah di Situbondo pada tanggal 24 Juni 2016

${ }_{17}$ Observasi lapak pedagang kaset kaki lima di Pasar Mimbaan Situbondo selama 2 bulan pada bulan September - Oktober 2017
} 
K.S, Theodore. 2013. Rock'n Roll Industri Musik Indonesia: Dari Analog ke Digital. Jakarta: Kompas Media Nusantara

Hidayatullah, P. 2017. Dangdut Madura Situbondoan. Yogyakarta: Diandra Kreatif

Spradley, James. P. 2006. Metode Etnografi. Yogyakarta: Tiara Wacana

Bruner, Edward M., dan Victor W. Turner. 1986. The Anthropology of Experience. Urbana and Chicago: University of Illinois Press.

Husson, Laurence. 1997. "Eight Centuries Of Madurese Migration to East Java”, dalam Asian and Pasific Migration Journal, Vol. 6, No. 1, 1997.

Weintraub, Andrew N. 2012. Dangdut: Musik, Identitas, dan Budaya Indonesia. Jakarta: Kepustakaan Populer Gramedia.

\section{Daftar Laman}

www.antropologi.info

\section{Daftar Informan}

1. Nama : Imam Kutunuk

Selaku : Budayawan Situbondo

Umur : 60an Tahun

2. Nama : Arif

Selaku : Pemilik Rahayu Inti Fantasi Record

Umur : 50an Tahun

3. Nama : Anto

Selaku : Sound Engineer Handayani Record

Umur : 40an Tahun

4. Nama : S. Pandi

Selaku : Penulis lagu dangdut Madura

Umur : 40an Tahun

5. Nama : Enni Silvana

Selaku : Pemilik toko kaset Bagong

Umur : 50an Tahun

6. Nama : Reno

Selaku : Penyiar radio Bhasa FM

Umur : 30an Tahun

7. Nama : Mama Ratan (nama udara radio)

Selaku : Penggemar radio Suara Besuki Indah

Umur : 50an Tahun 